\title{
Transcriptional Analysis Responding to Propanol Stress in Escherichia coli
}

Hye-Jin Park and Jin-Ho Lee*

Department of Food Science \& Biotechnology, Kyungsung University, Busan 608-736, Korea

Received February 16, 2012 /Revised March 14, 2012 /Accepted March 15, 2012

\begin{abstract}
We compared the transcriptome in response to propanol stress in wild-type and propanol-resistant mutant Escherichia coli using the DNA microarray technique. The correlation value of RNA expression between the propanol-treated wild type and the untreated-one was about 0.949 , and 50 genes were differentially expressed by more than twofold in both samples. The correlation value of RNA expression between the propanol-treated mutant and the untreated one was about 0.951 , and 71 genes in two samples showed differential expression patterns. However, the values between the wild type and mutant, regardless of propanol addition, were 0.974-0.992 and only 1-2 genes were differentially expressed in the two strains. The representative characteristics among differentially expressed genes in W3110 or P19 treated with propanol compared to untreated samples were up-regulation of hest shock response genes and down-regulation of genes relating to ribosome biosynthesis. In addition, many genes were regulated by transcription regulation factors such as ArcA, CRP, FNR, H-NS, GatR, or PurR and overexpressed by sigma factor $\mathrm{RpoH}$. We confirmed that $\mathrm{RpoH}$ mediated an important host defense function in propanol stress in E. coli W3110 and P19 by comparison of cell growth rate among the wild type, rpoH disruptant mutant, and rpoH-complemented strain.
\end{abstract}

Key words : Propanol, microarray array, ArcA, rpoH, Escherichia coli

\section{서 론}

재생 가능한 바이오매스(renewable biomass)로부터 Saccharomyces cerevisiae와 Clostridium과 같은 미생물에 의해 서 바이오 알코올류(bio-alcohols)인 에탄올(ethanol)과 부탄 올(butanol)이 생산된다[19,24]. 그러나, 이러한 화합물들은 미생물에 독성을 나타내기 때문에 배양액에 많이 축적되면 세포의 성장이 저해되고, 알코올 생산성이 저하되는 문제점 이 있다[20]. 따라서, 알코올류의 발효농도와 생산성을 향상 시키기 위해서는 알코올 축적에 따른 미생물내의 유전자 발 현, 단백질 합성, 대사흐름의 변화, 그에 따른 생리적인 변화 등에 관한 세포수준 및 분자수준에서의 종합적인 분석과 이 해가 필요하다.

알코올류 중, 특히 에탄올과 부탄올 스트레스가 미생물에 어떠한 영향을 미치는지에 대한 연구가 많이 이루어지고 있다 [20]. 세포가 에탄올에 노출될 경우, 세포의 형태(morphology) 뿐만 아니라 세포막의 조성(composition), 구조(structure), 그 리고 기능(function)에 변화가 일어나며, 또한, 세포분열 저해, 세포 생존성(viability) 감소, 대사활성(metabolic activity) 저 하 등이 나타나는 것으로 알려져 있다 $[1,17,26]$. S. cerevisiae에 서 microarray 를 사용하여 에탄올 내성에 관여하는 주요 조절 유전자들을 확인한 결과, TCA 회로, 해당과정, 아미노산 대사,

*Corresponding author

Tel : +82-51-633-4716, Fax : +82-51-622-4986

E-mail : jhlee83@ks.ac.kr
일반적인 스트레스 반응(general stress response), cell rescue defense, 그리고 virulence와 관련된 유전자들의 발현이 증가 하는 것으로 확인되었다[22]. Escherichia coli의 경우, 에탄올에 반응하여 세포막의 지방산 탄소 수가 16 개에서 18 개로 증가하 는 것이 보고되었으며[10,11], 그 외 3개의 대사물질(glycine, betaine, serine)과 하나의 기능성 전사인자(non-functional transcription factor, FNR)가 혐 기적인 E. coli 배양에서 에탄올 내성에 중요한 인자들임을 확인하였다[16]. 한편, Clostridium 세포가 부탄올에 노출될 경우, 영양물질의 능동수송[8], 막결 합 ATPase [8,30], 그리고 포도당 흡수가 저해되며, 세포막 주 위의 양성자동력(proton motive force)을 부분적으로 또는 완 전히 없애며, 세포 내 $\mathrm{pH}$ 와 ATP농도를 낮추는 것으로 알려져 있다[30]. 또한 세포막의 유동성을 유지하기 위해 포화지방산 의 비율이 증가하며 $[7,18]$, 열충격 단백질(heat shock proteins, $\mathrm{HSPs}$ )들의 발현도 증가하는 것이 밝혀졌다[3,31]. 특히, HSPs 의 일종인 GroEL을 많이 발현시킨 결과, 부탄올 내성과 농도 가 증가하는 결과를 얻었다[31]. Microarray 실험을 이용하여 또 다른 바이오알코올인 이소부탄올 스트레스에 대한 E. coli 에서의 분자수준에서 그 기작을 규명한 연구가 발표되었다[9]. E. coli가 이소부탄올에 노출되면, 세포막의 기능에 영향을 미 쳐 호흡에 관여하는 quinone의 기능에 손상을 주어, 최종적으 로ArcA, PhoB, Fur를 활성화시켜 각각의 regulons을 조절하 는 것으로 확인되었다.

최근 새로운 유전자들을 도입하여 대사공학적으로 개발된 E. coli를 이용하여 산업적으로 유용한 이소부탄올, 부탄올, 프 
로판올(propanol), 이소프로판올(isopropanol) 등의 고분자 바 이오 알코올류를 생산할 수 있는 기술이 보고되었다[4,5,29]. 그 중에서 프로판올은 에탄올보다 높은 에너지 밀도와 낮은 증기압을 갖는 에탄올을 대체할 수 있는 바이오연료로서의 가치가 있는 알코올이다[29]. 프로판올을 생산하는 E. coli를 개발하는데 있어 프로판올이 E. coli에 어떠한 유전적, 생리적, 대사적 영향을 미치는 지를 조사할 필요가 있다. 본 연구자들 은 E. coli를 배양하는 과정에서 프로판올이 전체 유전자들의 발현에 어떠한 영향을 미치며, 프로판올 내성에 관여하는 유 전자가 무엇인지를 DNA microarray 실험을 통하여 확인하였 다. 그 결과, sigma factor 중에서 특히, $\mathrm{RpoH}$ 에 의해서 조절받 는 유전자들의 발현이 많이 증가하며, 여러 global regulators 에 의해서 조절 받는 유전자들의 발현이 증가하거나 감소함을 확인하여 보고한다.

\section{재료 및 방법}

\section{균주 및 플라스미드}

Microarray 실험에는 야생주인 E. coli W3110과 W3110에 서 $\mathrm{UV}$ 를 이용하여 변이 처리하여 분리한 프로판올 내성주 E. coli $\mathrm{P} 19$ 를 사용하였다. E. coli W3110의 $r p o H$ 유전자를 파손하기 위한 공여균은 일본 NBRP (National BioResource Project) 에서 분양받은 transposon insertion disruptant 중 의 하나인 E. coli JD15211 (rpoH:Kn)를 사용하였으며[6], $\mathrm{W} 3110$ 에서 $\mathrm{rpoH}$ 가 파손된 E. coli DRP17은 프로판올 내성 효과 평가실험을 위한 균으로 이용하였다. $\mathrm{rpoH}$ 유전자의 클로닝을 위한 플라스미드는 pBeloBac11 (New England Biolabs, USA)을 사용하였다.

\section{배지 및 배양조건}

균주는 통상적으로 $37^{\circ} \mathrm{C}$ 에서 LB (Luria-Bertani) 배지를 사 용하여 호기적인 조건에서 진탕 배양하였으며, 항생제가 필요 시, kanamycin과 chloramphenicol은 각각 $25 \mu \mathrm{g} / \mathrm{ml}$ 와 $10 \mu$ $\mathrm{g} / \mathrm{ml}$ 을 첨가하였다[28]. P1 파지 형질도입에 사용하는 배지는 LGCM (tryptone $10 \mathrm{~g} / \mathrm{l}$, yeast extract $5 \mathrm{~g} / \mathrm{l}, \mathrm{NaCl} 5 \mathrm{~g} / \mathrm{l}$, glucose $2 \mathrm{~g} / \mathrm{l}, \mathrm{CaCl}_{2} 2 \mathrm{H}_{2} \mathrm{O} 0.01 \mathrm{mM}, \mathrm{MgSO}_{4} 7 \mathrm{H}_{2} \mathrm{O} 1 \mathrm{mM}$ )배지를 사용하였다. 전체 RNA 분리 및 프로판올 내성을 측정하기 위하여 $50 \mathrm{ml}$ 의 LB배지를 함유한 $250 \mathrm{ml}$ 의 삼각 플라스크를 사용하였으며, 세포성장은 분광광도계(Shimadzu UV mini1240 , Japan)를 이용하여 $600 \mathrm{~nm}$ 에서 흡광도를 측정하여 관찰 하였다.

\section{세포수확 및 RNA 정제}

전제 RNA를 분리하기 위해 야생주와 프로판올 내성주를 배양하다가 OD가 약 0.7 될 때, W3110과 P19 세포의 반은 프로판올을 $17.5 \mathrm{~g} / 1$ 를 첨가하고, 나머지 반은 프로판올을 첨
가하지 않은 다음 10 분이 경과한 후 세포 $1 \mathrm{ml}$ 을 취해 원심분 리 한 후 RNA later (Ambion, USA)를 첨가하여 보관한 다음, RNeasy Mini Kit (Qiagen, Dutch)를 사용하여 RNA를 분리하 였다. 정제된 RNA의 순도와 온전함(integrity)은 $260 \mathrm{~nm}$ 와 $280 \mathrm{~nm}$ 에서의 흡광도 비율을 계산하였으며, Agilent 2100 Bioanalyzer (Agilent Technologies, USA)를 사용하여 분석하 였다.

\section{Microarray 실험 및 분석}

cDNA 합성은 Nimblegen Expressoion protocol에 따라 SuperScript double-stranded cDNA synthesis kit (Invitrogen Life Technologies, USA)를 사용하였다. 즉, $10 \mu \mathrm{g}$ 의 total RNA로부터 random primer를 이용하여 역전사(reverse-transcription)하여 second-strand cDNA를 합성하고 정제 후 ND-1000 Spectrophotometer (NanoDrop, USA)로 정량하였 다. cDNA는 Nimblegen Expression protocol에 따라서 One-Color Labeling Kit (Nimblegen)를 사용하여 라벨링하였 다. $1 \mu \mathrm{g}$ 의 cDNA 샘플을 Cy3-random nonamer를 사용하여 $\mathrm{Cy} 3$ 로 라벨링한 다음 ND-1000 Spectrophotometer로 정량하 였다. Labeled cDNA 샘플은 $42^{\circ} \mathrm{C}$ 에서 16-20시간 Nimblegen Expression array ( $E$. coli $4 \times 72 \mathrm{~K}$ array)와 혼성화하였다. Arrays는 $532 \mathrm{~nm}$ 에서 $2 \mu \mathrm{m}$ 의 해상도로 NimbleGen MS 200 Microarray scanner set로 스캐닝하여 TIFF format으로 이미 지를 만들었다. NimbleScan v2.5를 사용하여 array data를 추 출가공하고 분석하였다. 미가공 data는 NimbleScan v2.5 (Gene Expression RMA algorithm)를 사용하여 추출하였다. 2,535 개 유전자 각각의 24 개 probes의 평균 spot replicates로 부터 single raw intensity value를 결정하였다. 발현 data의 통계적 중요성은 fold change로 결정하였다. Hierarchical cluster 분석은 complete linkage와 Euclidean distance로 결정 하였다.

\section{$\mathrm{rpoH}$ disruptant 균주제작}

Bacteriophage P1 lysate를 제작하기 위해 유전자 공여균주 (donor cell)인 E. coli JD15211을 kanamycin을 함유한 $3 \mathrm{ml}$ $\mathrm{LB}$ 배지에 접종하여 $37^{\circ} \mathrm{C}$ 에서 16 시간 진탕배양 후 $2 \mathrm{ml} \mathrm{LGCM}$ 배지에 $1 \%$ 를 접종하여 $\mathrm{OD}$ 가 0.2 가 될 때까지 배양한 다음 P1 phage를 $20 \mu \mathrm{l}$ 주입하여 세포가 lysis될 때까지(약 2 3시간) 배양하였다. 배양액에 클로로포름 $100 \mu$ 를 주입하여 잘 현탁 시킨 후 30 분간 실온에서 방치시킨 후 2회 원심 분리한 다음 상등액에 클로로포름 $50 \mu$ 를 현탁하여 $4^{\circ} \mathrm{C}$ 에 보관하였다. 제 작한 P1 lysate를 수용균주(recipient cell)인 E. coli W3110에 감염시키기 위하여 $3 \mathrm{ml}$ 의 $\mathrm{LB}$ 배지에 접종하여 16 시간 동안 배양한 후 $2 \mathrm{ml} \mathrm{LGCM}$ 배지에 $1 \%$ 를 접종하여 OD가 0.5 가 될 때까지 진탕배양하였다. 배양액 $1 \mathrm{ml}$ 을 원심분리 후 침전물을 $100 \mu \mathrm{l}$ 의 LGCM배지에 현탁시킨 다음 상기에서 제작한 P1 ly- 
sate를 $20 \mu \mathrm{l}$ 주입하여 30 분간 $37^{\circ} \mathrm{C}$ 에서 진탕배양 시킨 후 0.1 $\mathrm{M}$ sodium citrate (pH 5.8) 완충액으로 3회 세척하였다. 이를 $0.1 \mathrm{M}$ sodium citrate $100 \mu \mathrm{l}$ 에 현탁 시킨 후 kanamycin이 함유된 $\mathrm{LB}$ 에 도말하여 $37^{\circ} \mathrm{C}$ 에서 성장하는 colony를 순수 분리 하여 최종적으로 E. coli DRP17를 선별하였다.

\section{$\mathrm{rpoH}$ 유전자 클로닝}

E. coli에 존재하는 $\mathrm{rpoH}$ 유전자를 클로닝하기 위해 다음과 같은 primer를 제작하였다. Forward primer의 $5^{\prime}$ 말단에는 $\operatorname{BamHI}$, reverse primer의 $5^{\prime}$ 말단에는 $S p h$ 제한효소 인식서열 을 삽입하였다(forward primer: CCGCGGATCCGGGTGGC AGCGTGGCTTGCC; reverse primer: ACATGCATGCTGC CAGTAACGCTTTACCCT). Pfu-X polymerase (Solgent, Korea)를 이용하여 E. coli W3110에서 추출한 염색체를 주형 $\mathrm{DNA}$ 로 사용하여 $95^{\circ} \mathrm{C} 20$ 초, $55^{\circ} \mathrm{C} 30$ 초, $72^{\circ} \mathrm{C} 45$ 초의 조건으로 30 cycle의 polymerase chain reaction을 수행하였다. 정제한 $\mathrm{rpoH}$ 유전자 단편 $1.46 \mathrm{~kb}$ 와 클로닝 벡터 $\mathrm{pBeloBac11}$ 을 각각 $B a m H I$ 과 $S p h$ 제한효소로 이중절단하고, 다시 ligation하여 재조합 plasmid pBRH46을 제작하고 염기서열을 확인하였다.

\section{결과 및 고찰}

프로판올 첨가에 따른 전체 전사체 비교분석 및 해석

세포의 프로판올 내성도, 세포배양 및 RNA 정제: 야생주인 E. coli W3110은 $10 \mathrm{~g} / 1$ 이상의 프로판올에서 세포의 성장이 급격히 저해되며 $20 \mathrm{~g} / 1$ 이상에서는 거의 완전히 정지 된다. 반면 프로판올 내성주 P19의 경우, W3110과 비교하여 상대적으로 높은 프로판올 내성을 보여주었다(Fig. 1A). 또한, 균을 배양하면서 대수기 중간단계인 OD 0.7정도에서 프로판 올을 첨가하면, 두 균의 세포 성장이 저해됨을 알 수 있으며, $\mathrm{P} 19$ 보다 W3110이 더 프로판올에 민감하게 세포의 성장이 저 해됨을 알 수 있었다(Fig. 1B). 두 균주에 대한 프로판올 첨가에 의한 초기 전체 유전자들의 발현을 분석하기 위해, $\mathrm{OD} 0.7$ 에 서 프로판올을 첨가한 다음 10 분 후에 $\mathrm{RNA}$ 를 정제하였다. 정제한 $\mathrm{RNA}$ 시료의 흡광도 비 $\left(\mathrm{A}_{260 / 280}\right)$ 는 2.1로 기준치인 1.8 이상 이였으며, $23 \mathrm{~S}$ 와 $16 \mathrm{~S} \mathrm{rRNA}$ 의 비율도 2:1의 비율을 이루 어 RNA의 integrity를 확인하였다(Fig. 2).

전체적인 발현 profile 해석: 시료간의 전체적인 RNA 발현 의 유사성을 비교하기 위하여 Pair-wise scatter plots 한 결과, 프로판올 무첨가한 W3110 (W1)과 P19 (P1) 사이의 연관값 (correlation value)은 0.992로 매우 높으며, 그 다음으로 프로 판올 첨가한 $\mathrm{W} 3110(\mathrm{~W} 2)$ 과 $\mathrm{P} 19(\mathrm{P} 2)$ 사이에 0.974로 높은 반 면에, 각각의 균주에서 프로판올 첨가유무에 따른 유전자의 발현비율은 많이 변화하여 야생주의 경우 0.949 (W2/W1), 프 로판올 내성주의 경우 0.952 (P2/P1)를 나타냈다(Fig. 3). 이는 프로판올을 첨가하지 않은 경우, 야생주와 프로판올 내성주
(A)

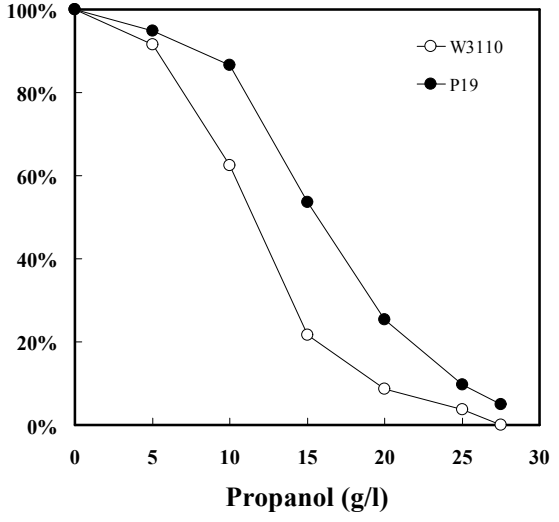

(B)



Fig. 1. Growth curve of E. coli W3110 and P19 in response to propanol addition. (A) Both strains were cultured in LB medium with $0 \sim 27.5 \mathrm{~g} / 1$ of propanol for $16 \mathrm{hr}$ at $37^{\circ} \mathrm{C}$. (B) After $2 \mathrm{hr}$ cultivation (indicated in arrow) in LB medium, one half of both strains (W3110+P, closed circle; $\mathrm{P} 19+\mathrm{P}$, closed triangle) received $17.5 \mathrm{~g} / \mathrm{l}$ of propanol and the other remained untreated (W3110, open circle; P19, open triangle). Each measurement was performed in triplicate. Cells were taken for microarray experiment after $10 \mathrm{~min}$ cultivation. This experiment was conducted one time.

모두 RNA의 발현양상이 매우 유사함을 의미하며, 마찬가지 로 프로판올을 첨가한 경우에도 두 균주사이의 RNA 발현양 상이 매우 유사함을 의미한다. 한편, 야생주 및 프로판올 내성 주에서 프로판올의 첨가유무에 따른 연관값(W2/W1, P2/P1) 은 상대적으로 낮은 수치를 보인 것은 프로판올을 첨가하면 많은 유전자들의 발현이 변화함을 알 수 있었다. 이는 2배 이 상의 발현의 차이를 나타내는 유전자사이의 Hierarchical clustering을 통한 분석에서도 W1과 $\mathrm{P} 1, \mathrm{~W} 2$ 와 $\mathrm{P} 2$ 의 발현양상 이 매우 유사함을 보여주었다(Fig. 4).

\section{균주별 프로판올 첨가에 따른 전사체 발현 분석 및 해석}

프로판올 첨가에 의해서 2 배 이상 발현에 변화가 있는 유전 자는, 야생주의 경우(W2/W1) 50 개의 유전자의 변화가 관찰 


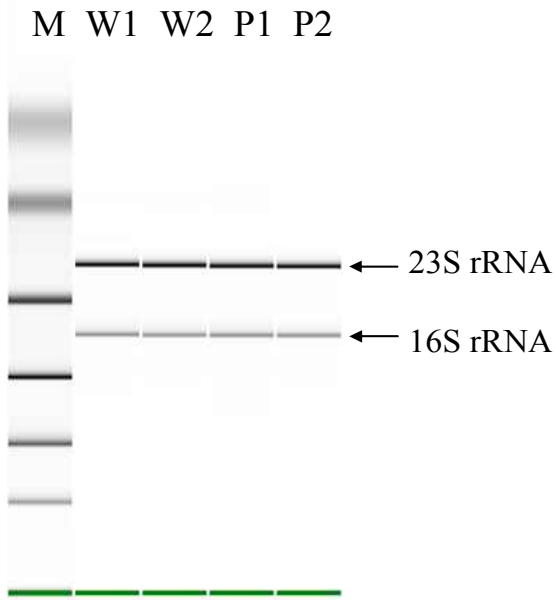

Fig. 2. RNA electrophoresis pattern of purified RNAs from 4 samples. M, molecular weight size marker; W1, purified RNA sample from propanol-untreated W3110; W2, purified RNA sample from propanol-treated W3110 for 10 min; P1, purified RNA sample from propanol-untreated P19; P2, purified RNA sample from propanol-treated P19 for $10 \mathrm{~min}$.

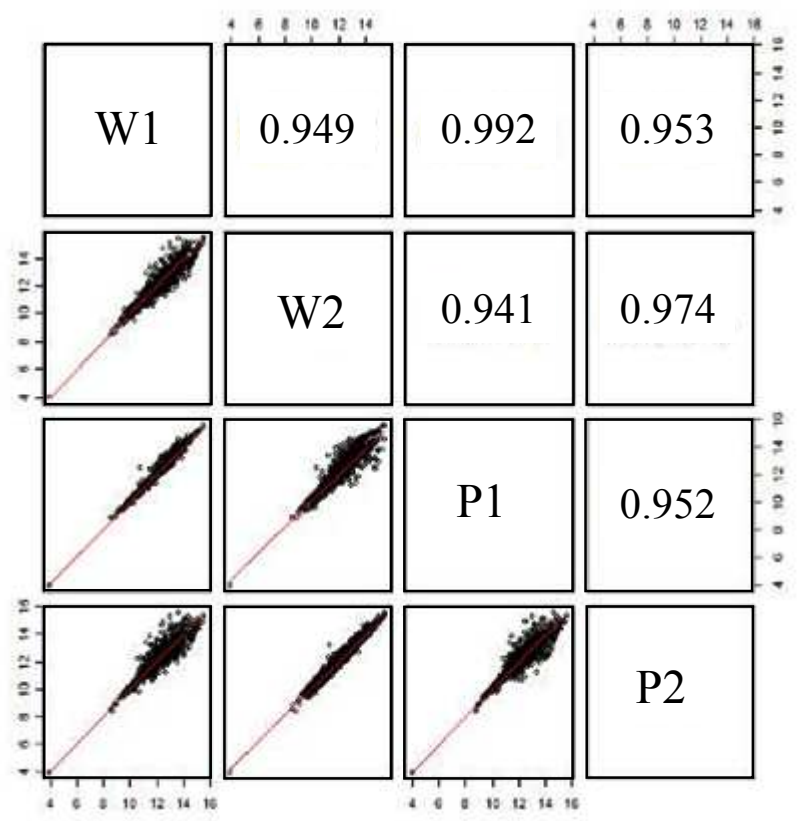

Fig. 3. Pair-wise scatter plots among W1, W2, P1, and P2.

되었으며, 프로판올 내성주의 경우(P2/P1) 71 개의 유전자의 변화, 프로판올 무처리한 변이주와 야생주를 비교하면 (P1/W1) 1개, 프로판올 처리한 변이주와 야생주(P2/W2)는 2 개의 유전자가 발현에 큰 변화를 보여주었다(Table 1,2,3). 즉, 야생주와 변이주 모두 프로판올을 첨가하면 프로판올 스트레 스에 의해서 유전자들의 발현이 급격히 변화됨을 보여주었다.

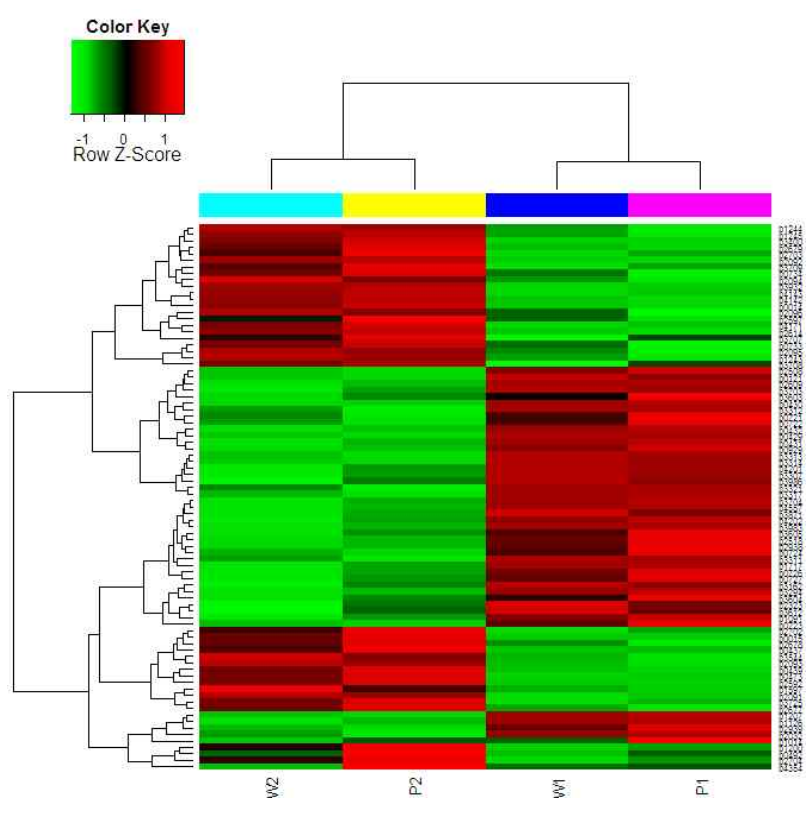

Fig. 4. Hierarchical clustering of genes showing differential expression more than 2 fold in W1, W2, P1, or P2.

반면, 프로판올을 무처리 또는 처리한 상태에서 두 균주의 전 사체를 비교하면 발현이 거의 차이가 없음을 보여주었다. 이 는 UV처리에 의한 프로판올 내성이 유전자 발현에 기인한 것이 아니라 특정 단백질의 특성 등의 변화에 의한 것으로 사료된다.

야생주에서 프로판올 첨가에 따른 RNA 발현 비교분석: 프로판올을 무첨가한 야생주(W1)와 첨가한 야생주(W2) 사이 의 RNA 발현을 비교 분석한 결과, 프로판올 첨가에 따라 발현 이 증가된 유전자들은 heat shock response에 관련된 8개의 유전자, acid-shock response에 관련된 1 개의 유전자, galactitol 당 수송에 관여하는 4개의 유전자, oligopeptide 수송에 관여하는 2개 유전자 등이었다. 반면 발현이 억제된 유전자들 은 ribosome 합성에 필요한 유전자 11개, respiratory chain에 관련된 4 개 유전자, TCA cycle에 관련된 3 개 유전자, 지방산 합성에 관련된 2개 유전자, 트립토판 분해에 관련된 1개 유전 자 등이 있었다.

프로판올 내성주에서 프로판올 첨가에 따른 RNA 발현 비교분석: 프로판올을 무첨가한 프로판올 내성 변이주(P1)와 첨가한 변이주 $(\mathrm{P} 2)$ 사이의 RNA 발현을 비교 분석한 결과, 프 로판올 처리에 따라 up regulation 된 유전자는 heat shock response에 관련된 11개 유전자, glucitol과 galactitol 과 같은 당 수송 및 대사에 관련된 8개의 유전자, oligopeptide 수송에 관여하는 4 개의 유전자, glycine betaine 수송에 관여하는 유전 자 3개, 트립토판 수송 및 분해에 관련된 3개 유전자, respiratory chain에 관련된 2 개 유전자, 글리세롤 분해에 관련된 1 개 유전자 등이 있었다. Down regulation된 유전자는 ribosome 
Table 1. Genes showing a significant differential expression between W2 and W1

\begin{tabular}{|c|c|c|}
\hline Gene & Function & Fold \\
\hline \multicolumn{3}{|c|}{ Increased expression in W2 compared to W1 } \\
\hline groL & Cpn60 chaperonin GroEL, large subunit of GroESL & 4.70 \\
\hline gros & Cpn10 chaperonin GroES, small subunit of GroESL & 4.47 \\
\hline dnaK & chaperone Hsp70, co-chaperone with DnaJ & 3.88 \\
\hline$c l p B$ & protein disaggregation chaperone & 3.56 \\
\hline tnaA & tryptophanase/L-cysteine desulfhydrase & 3.39 \\
\hline htpG & molecular chaperone HSP90 family & 3.20 \\
\hline$h s l V$ & peptidase component of the HslUV protease & 2.92 \\
\hline$d p p A$ & dipeptide transporter & 2.86 \\
\hline tnaC & tryptophanase leader peptide & 2.75 \\
\hline gat $B$ & galactitol-specific enzyme IIB component of PTS & 2.66 \\
\hline $\operatorname{mia} A$ & delta(2)-isopentenylpyrophosphate tRNA-adenosine transferase & 2.57 \\
\hline gatC & galactitol-specific enzyme IIC component of PTS & 2.43 \\
\hline gat $A$ & galactitol-specific enzyme IIA component of PTS & 2.37 \\
\hline lon & DNA-binding ATP-dependent protease La & 2.20 \\
\hline oppA & oligopeptide transporter subunit & 2.17 \\
\hline$h s l R$ & ribosome-associated heat shock protein Hsp15 & 2.12 \\
\hline asr & acid shock-inducible periplasmic protein & 2.08 \\
\hline dnal & chaperone Hsp40, co-chaperone with DnaK & 2.04 \\
\hline gatD & galactitol-1-phosphate dehydrogenase & 2.03 \\
\hline \multicolumn{3}{|c|}{ Decreased expression in $\mathrm{W} 2$ compared to $\mathrm{W} 1$} \\
\hline cyoC & cytochrome o ubiquinol oxidase subunit III & -3.29 \\
\hline$C y o B$ & cytochrome o ubiquinol oxidase subunit I & -3.09 \\
\hline sucA & 2-oxoglutarate decarboxylase & -3.02 \\
\hline$s u c B$ & dihydrolipoyltranssuccinase & -2.94 \\
\hline$o m p F$ & outer membrane porin $1 \mathrm{a}$ & -2.76 \\
\hline dea $D$ & ATP-dependent RNA helicase & -2.65 \\
\hline sdh $A$ & succinate dehydrogenase, flavoprotein subunit & -2.61 \\
\hline$r p l K$ & 50 S ribosomal subunit protein L11 & -2.57 \\
\hline $\operatorname{rps} Q$ & $30 S$ ribosomal subunit protein $\mathrm{S} 17$ & -2.53 \\
\hline $\operatorname{rps} P$ & $30 S$ ribosomal subunit protein S16 & -2.49 \\
\hline rpmC & 50 S ribosomal subunit protein L29 & -2.47 \\
\hline rpsR & $30 S$ ribosomal subunit protein S18 & -2.38 \\
\hline cyoA & cytochrome o ubiquinol oxidase subunit II & -2.37 \\
\hline mpA & protein $\mathrm{C} 5$ component of RNase $\mathrm{P}$ & -2.31 \\
\hline rplQ & $50 S$ ribosomal subunit protein L17 & -2.30 \\
\hline$f a b B$ & 3-oxoacyl-[acyl-carrier-protein] synthase I & -2.25 \\
\hline yid & predicted protein & -2.23 \\
\hline pot $A$ & polyamine transporter subunit & -2.23 \\
\hline$c y o D$ & cytochrome o ubiquinol oxidase subunit IV & -2.22 \\
\hline typA & GTP-binding protein & -2.21 \\
\hline $\operatorname{rps} C$ & $30 \mathrm{~S}$ ribosomal subunit protein S3 & -2.18 \\
\hline$n d k$ & multifunctional nucleoside diphosphate kinas & -2.15 \\
\hline priB & primosomal protein $\mathrm{N}$ & -2.15 \\
\hline$r p s N$ & $30 S$ ribosomal subunit protein S14 & -2.14 \\
\hline rpmI & $50 S$ ribosomal subunit protein L35 & -2.13 \\
\hline $\mathrm{fabH}$ & 3-oxoacyl-[acyl-carrier-protein] synthase III & -2.11 \\
\hline rpmH & 50 S ribosomal subunit protein L34 & -2.10 \\
\hline rplL & $50 \mathrm{~S}$ ribosomal subunit protein L7/L12 & -2.05 \\
\hline prs & phosphoribosylpyrophosphate synthase & -2.04 \\
\hline gpmM & phosphoglycero mutase III, cofactor-independent & -2.04 \\
\hline speE & spermidine synthase (putrescine aminopropyltransferase) & -2.03 \\
\hline
\end{tabular}


Table 2. Genes showing a significant differential expression between P2 and P1

\begin{tabular}{|c|c|c|}
\hline Gene & Function & Fold \\
\hline \multicolumn{3}{|c|}{ Increased expression in P2 compared to P1 } \\
\hline gras & Cpn10 chaperonin GroES, small subunit of GroESL & 5.53 \\
\hline$c l p B$ & protein disaggregation chaperone & 5.36 \\
\hline groL & Cpn60 chaperonin GroEL, large subunit of GroESL & 5.15 \\
\hline dnaK & chaperone Hsp70, co-chaperone with DnaJ & 5.03 \\
\hline htpG & molecular chaperone HSP90 family & 4.37 \\
\hline lon & DNA-binding ATP-dependent protease La & 3.17 \\
\hline $\operatorname{miaA}$ & delta(2)-isopentenylpyrophosphate tRNA-adenosine transferase & 3.15 \\
\hline$h s l V$ & peptidase component of the HslUV protease & 3.02 \\
\hline yii & predicted inner membrane protein & 2.81 \\
\hline dnaI & chaperone Hsp40, co-chaperone with DnaK & 2.74 \\
\hline $\operatorname{cyd} d B$ & cytochrome d terminal oxidase, subunit II & 2.73 \\
\hline $\operatorname{srl} B$ & glucitol/sorbitol-specific enzyme IIA component of PTS & 2.71 \\
\hline$d p p A$ & dipeptide transporter & 2.64 \\
\hline srlA & glucitol/sorbitol-specific enzyme IIC component of PTS & 2.60 \\
\hline $\operatorname{cyd} A$ & cytochrome d terminal oxidase, subunit I & 2.59 \\
\hline gat $B$ & galactitol-specific enzyme IIB component of PTS & 2.59 \\
\hline gatC & galactitol-specific enzyme IIC component of PTS & 2.59 \\
\hline proW & glycine betaine transporter subunit & 2.55 \\
\hline tnaC & tryptophanase leader peptide & 2.52 \\
\hline$h s l R$ & ribosome-associated heat shock protein Hsp15 & 2.47 \\
\hline oppA & oligopeptide transporter subunit & 2.45 \\
\hline srlE & glucitol/sorbitol-specific enzyme IIB component of PTS & 2.43 \\
\hline proV & glycine betaine transporter subunit & 2.41 \\
\hline proX & glycine betaine transporter subunit & 2.39 \\
\hline gat $A$ & galactitol-specific enzyme IIA component of PTS & 2.31 \\
\hline gat $Y$ & D-tagatose 1,6-bisphosphate aldolase 2, catalytic subunit & 2.25 \\
\hline grpE & heat shock protein & 2.22 \\
\hline gat $Z$ & D-tagatose 1,6-bisphosphate aldolase 2, subunit & 2.20 \\
\hline$o p p B$ & oligopeptide transporter subunit & 2.15 \\
\hline$y b b N$ & predicted thioredoxin domain-containing protein & 2.13 \\
\hline$c l p P$ & ATP-dependent serine proteases & 2.12 \\
\hline $\operatorname{tn} a B$ & tryptophan transporter of low affinity & 2.12 \\
\hline pstB & phosphate transporter subunit & 2.09 \\
\hline oppC & oligopeptide transporter subunit & 2.04 \\
\hline raiA & cold shock protein associated with $30 \mathrm{~S}$ ribosomal subunit & 2.04 \\
\hline dhaK & dihydroxyacetone kinase, N-terminal domain & 2.03 \\
\hline \multicolumn{3}{|c|}{ Decreased expression in P2 compared to P1 } \\
\hline$s d h A$ & succinate dehydrogenase, flavoprotein subunit & -4.42 \\
\hline SUCA & 2-oxoglutarate decarboxylase, thiamin-requiring & -3.50 \\
\hline cyoC & cytochrome o ubiquinol oxidase subunit III & -3.41 \\
\hline$s u c B$ & dihydrolipoyltranssuccinase & -3.41 \\
\hline$s d h D$ & succinate dehydrogenase, membrane subunit & -3.34 \\
\hline putA & proline dehydrogenase/pyrroline-5-carboxylate dehydrogenase & -3.11 \\
\hline$r p s Q$ & $30 \mathrm{~S}$ ribosomal subunit protein S17 & -3.08 \\
\hline rpmC & $50 S$ ribosomal subunit protein L29 & -3.06 \\
\hline ompF & outer membrane porin $1 \mathrm{a}(\mathrm{Ia} ; \mathrm{b} ; \mathrm{F})$ & -3.04 \\
\hline$s d h C$ & succinate dehydrogenase, membrane subunit & -2.97 \\
\hline$C y o B$ & cytochrome o ubiquinol oxidase subunit I & -2.88 \\
\hline$y q g B$ & predicted protein & -2.88 \\
\hline$n d k$ & nucleoside diphosphate kinase & -2.81 \\
\hline
\end{tabular}


Table 2. Continued

\begin{tabular}{|c|c|c|}
\hline Gene & Function & Fold \\
\hline \multicolumn{3}{|c|}{ Decreased expression in P2 compared to P1 } \\
\hline IldR & DNA-binding transcriptional repressor & -2.63 \\
\hline CyoA & cytochrome o ubiquinol oxidase subunit II & -2.38 \\
\hline$r p I K$ & 50 S ribosomal subunit protein L11 & -2.36 \\
\hline $11 d D$ & L-lactate dehydrogenase & -2.33 \\
\hline $\operatorname{rps} P$ & $30 S$ ribosomal subunit protein S16 & -2.30 \\
\hline$s d h B$ & succinate dehydrogenase, $\mathrm{FeS}$ subunit & -2.30 \\
\hline rplQ & 50 S ribosomal subunit protein L17 & -2.27 \\
\hline cyoD & cytochrome o ubiquinol oxidase subunit IV & -2.25 \\
\hline prs & phosphoribosylpyrophosphate synthase & -2.24 \\
\hline rpsR & 30 S ribosomal subunit protein $\mathrm{S} 18$ & -2.20 \\
\hline rnpA & protein $\mathrm{C} 5$ component of RNase $\mathrm{P}$ & -2.18 \\
\hline yid & predicted protein & -2.13 \\
\hline $\operatorname{rps} C$ & 30 S ribosomal subunit protein S3 & -2.13 \\
\hline $\operatorname{pot} A$ & polyamine transporter subunit & -2.12 \\
\hline$r p l B$ & 50 S ribosomal subunit protein L2 & -2.10 \\
\hline gua $B$ & IMP dehydrogenase & -2.08 \\
\hline$w b b K$ & lipopolysaccharide biosynthesis protein & -2.06 \\
\hline rps J & $30 S$ ribosomal subunit protein $\mathrm{S} 10$ & -2.05 \\
\hline$r p l P$ & 50 S ribosomal subunit protein L16 & -2.03 \\
\hline speA & arginine decarboxylase & -2.01 \\
\hline IldP & L-lactate permease & -2.01 \\
\hline $\operatorname{pot} C$ & polyamine transporter subunit & -2.00 \\
\hline
\end{tabular}

Table 3. Genes showing increased expression between P1 and W1 and between P2 and W2, respectively

\begin{tabular}{lrc}
\hline Gene & Function & Fold \\
\hline Increased expression in P1 compared to W1 & \\
put $A$ & Proline dehydrogenase/pyrroline-5-carboxylate dehydrogenase & 3.20 \\
Increased expression in P2 compared to W2 & 3.88 \\
yjiY & predicted inner membrane protein & 2.17 \\
ybbN & predicted thioredoxin domain-containing protein \\
\hline
\end{tabular}

합성에 필요한 유전자 10 개, TCA cycle과 관련 6개 유전자, respiratory chain에 관련된 4 개 유전자, lactate 대사에 관련된 3 개 유전자 등 이었다.

프로판올 무처리한 변이주(P1)와 야생주(W1) 사이의 RNA발현 비교분석: P1과 W1사이의 발현을 비교한 결과 2배 이상 up regulation 된 유전자는 proline dehydrogenase 발현 에 필요한 1 개 유전자(putA)이며, 1.8 배 이상 up regulation 된 유전자는 트립토판 분해유전가 2개, glutamate/aspartate transporter 1 개였다.

프로판올 처리한 변이주(P2)와 야생주(W2) 사이의 RNA 발현 비교분석: $\mathrm{P} 2$ 와 $\mathrm{W} 2$ 사이의 발현에서 2배 이상 up regulation 된 유전자는 yjiY (predicted inner membrane protein) 와 $y b b N$ (putative thioredoxin-like protein) 이었다.

위에서 언급한 결과에서, 발현 변화를 나타내는 공통적인
특징으로는, 야생주와 프로판올 내성주 모두 heat shock response에 관련된 유전자들의 발현이 크게 증가하였으며, ribosome 생합성에 필요한 유전자들은 발현이 크게 저하되었다. 프로판올 스트레스에서 표현형으로 나타나는 대표적인 특징 중의 하나는 세포들의 성장이 급격히 저하되는 현상이다(Fig. $1 \mathrm{~B})$. 이는 리보소옴 합성에 필요한 단백질을 암호화하는 유전 자들의 발현 감소 현상과 세포의 성장저하라는 생리적인 특징 과 잘 일치함을 알 수 있었다.

전사조절인자(transcription regulation factors)에 의해
반응하는 유전자의 해석
야생주 또는 내성주에서 프로판올 처리에 따라 발현이 2
배 이상 변화하는 유전자들 중에서, $E$. coli의 대사를 global
하게 조절하는 전사조절인자들에 의해 조절을 받는지를 조


Table 4. Transcription regulation factors related with differentially expressed genes in W2 or P2 compared to W1 or P1, respectively, in response to propanol stress

\begin{tabular}{|c|c|c|}
\hline Transcription factors & Up-regulation genes & Down-regulation genes \\
\hline ArcA & $\begin{array}{l}\text { cydAB, gat } Y Z A B C D, \\
\text { opp } A B C, \text { tna } C A B\end{array}$ & $\begin{array}{l}\text { cyo } A B C D, I I d P R D, r p I B, r p l P, r p m C, r p s C \\
r p s P, r p s Q \text { sdhCDAB, sucAB, }\end{array}$ \\
\hline CRP & gat $Y Z A B C D$, srlAEB, tna $C A B$ & cyo $A B C D$, gua $B$, sdh $C D A B, \operatorname{suc} A B$ \\
\hline FNR & - & $\begin{array}{l}\text { суоABCD, rplB, rplP, rplJ, } \\
\operatorname{rps} C, r p s P, \operatorname{rps} Q, \text { rpmC, } \\
\text { sdhCDAB, suc } A B\end{array}$ \\
\hline H-NS & ast, cydA,B, proWX, srlAEB & - \\
\hline GatR & gat $Y Z A B C D$ & - \\
\hline PurR & - & guab, prs, spe $A$ \\
\hline
\end{tabular}

사하기 위해 Regulation $\mathrm{DB}$ 를 이용하여 확인한 결과를 Table 4에 표기하였다[15]. 산소호흡을 조절하는 ArcA [2], 당 대사 및 여러 다양한 유전자를 조절하는CRP (cAMP repressor protein) [14], anaerobic growth를 조절하는 FNR [27], 환경변화와 스트레스적응에 관여하는 H-NS (histonelike nucleoid structuring protein)[25], galactitol 수송과 대 사를 조절하는 GatR [21], 퓨린 생합성을 조절하는 PurR과 같은 조절인자들에 의해 프로판올 스트레스에 반응하는 유 전자들이 조절을 받는 것을 알 수 있었다. 특히, 정체기나 산 소 공급이 낮을 때 발현되는 $c y d A B$, 대수기 또는 산소 공급 이 원활할 때 발현되는 $C y o A B C D$, succinate를 산화하는 $s d h C D A B$ 는 대표적인 $\mathrm{ArcA}$ 활성화에 의해서 조절되는 유전 자들이다[13,23]. E. coli에서 isobutanol response network 연 구결과에 의하면, isobutanol stress를 받으면 세포막에 존재 하는 isoprenoid side chain를 지닌 전자전달 수용체인 quinine/quinol의 기능이 손상을 입게 되며, 그로 인해 quinone 에 의해서 작용이 억제되는 $\mathrm{ArcB}$ 가 인산화되면서 활성화되 고, 그로 인해 $\mathrm{ArcA}$ 가 인산화되어 활성화되어, $\mathrm{ArcA}$ sensing response가 나타남을 증명하였다[9]. 본 연구에서도 많은 ArcA sensing 유전자들의 발현이 변화하는 것은 대장균 야 생주 및 프로판올 내성주 모두 프로판올 스트레스에 의해서 세포막이 손상을 입게 되고, 그로 인해 quinone이 기능을 못 하게 되어서 최종적으로 $\mathrm{ArcA}$ sensing 유전자들의 발현이 나타나는 것으로 사료된다. 한편, $\mathrm{ArcA}$ 및 $\mathrm{FNR}$ 에 의해서 공 통적으로 $s d h C D A B$ 와 $s u c A B$ 가 repression되므로, 프로판올 스트레스에 의해서 대장균은 TCA cycle이 정상적으로 작동 되지 않을 수 있을 것으로 여겨진다. 시그마인자(sigma factors)에 반응하는 유전자의 해석 및 $\mathrm{rpoH}$ 효과

야생주 또는 내성주에서 프로판올 처리에 따라 발현이 크게 변화하는 유전자들과 RNA polymerase의 여러 sigma factors 중에서 일반적 인자인 $\mathrm{RpoD}$ 를 제외한 나머지 인자들과의 연 관관계를 분석하였다(Table 5). 11 개의 유전자가 heat shock resposne 를 매개하는 $\mathrm{RpoH}$ 에 의해서 발현이 상승하였다. 일 반적으로, heat shock response는 열에 의해 활성화되어 고온 에서 미생물 생존을 증가시키는 중요한 적응 기작으로, 열에 의해 변성되는 세포 내 단백질을 보호하는 chaperones과 세포 내 손상을 입은 단백질을 분해하는 단백질을 암호화하는 유전 자들을 발현 함으로서 이루어 진다[12]. 본 연구에서 과 발현되 는 유전자들도 chaperones과 proteases관련 유전자들이었다. 이는 E. coli에서 프로판올 스트레스에 의한 외부충격을 극복 하면서 세포가 생존하기 위한 보호기작으로 heat shcok response 에 관련된 유전자를 과 발현하는 것으로 사료된다. Clostridium에서 butanol을 첨가 한 균주의 microarray 실험 결과에서도 heat shock proteins들이 많이 발현되는 결과와 잘 일치한다[3]. 또한, GroEL을 많이 발현시킨 결과, 부탄올 내성과 농도가 증가하는 결과를 얻었다[31]. 따라서, HSPs의 발현은 알코올류에 의한 스트레스를 극복하기 위한 세포의 공통적인 보호기작으로 생각되어진다. 한편, 대장균에서 $\mathrm{RpoH}$ 가 프로판올 내성에 관련이 있는지를 확인하기 위해서 야생주와 $r p o H$ 가 정상적으로 발현되지 못하는 변이주 (DRP17)를 사용하여 대수기까지 세포를 배양하다가 프로판올 을 첨가하여 세포의 성장이 어떻게 변화하는지를 관찰하였다 (Fig. 5). 그 결과, $\mathrm{rpoH}$ 변이주는 프로판올 처리에 의해 야생주

Table 5. Classification of sigma factors and sensing genes by propanol stress in W2 or P2 compared to W1 or P1, respectively

\begin{tabular}{ll}
\hline Sigma factors & Up-regulation genes \\
\hline RpoE & lon \\
RpoF & $o p p A B C$ \\
RpoH & $c l p B, c l p P, d n a J, d n a K$, hslR, hslV, htpG, groL, groS, grpE, ybbN \\
RpoS & $a s r, d h a K$, proV, pstB \\
\hline
\end{tabular}


Table 6. Specific growth rate of E. coli W3110, DRP17, and DRP17/pBRH46 in LB medium without propanol or with propanol

\begin{tabular}{|c|c|c|c|c|c|c|}
\hline \multirow{2}{*}{ E. coli } & \multicolumn{2}{|c|}{ W3110 } & \multicolumn{2}{|c|}{ DRP17 } & \multicolumn{2}{|c|}{ DRP17/pBRH46 } \\
\hline & without propanol & with propanol & without propanol & with propanol & without propanol & with propanol \\
\hline $\begin{array}{l}\text { Specific } \\
\text { growth rate }(/ h)^{*}\end{array}$ & 1.018 & 0.445 & 0.982 & 0.304 & 0.996 & 0.424 \\
\hline
\end{tabular}

${ }^{*}$ Specific growth rate was calculated based on growth curve in Fig. 5.

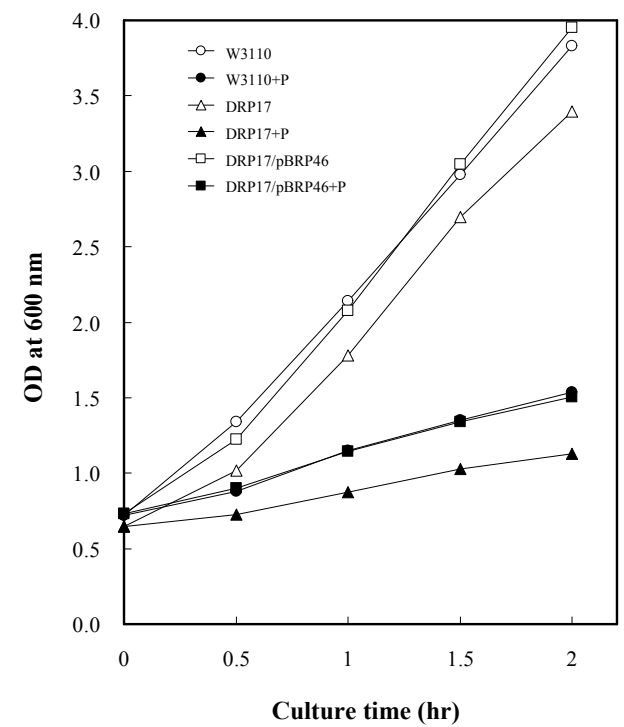

Fig. 5. Effect of $r p o H$ gene in response to propanol-stress in wild type E. coli W3110, rpoH disruptant DPR17, and rpoH-c omplemented DRP17/pBRH46. All of cells were grown in $500 \mathrm{ml}$ flask containing $100 \mathrm{ml} \mathrm{LB}$ medium. When cell OD reaches about $0.6 \sim 0.7,50 \mathrm{ml}$ of three types of cells were transferred to $250 \mathrm{ml}$ flask harboring $17.5 \mathrm{~g} / 1$ of propanol, respectively, whereas $50 \mathrm{ml}$ of 3 cells were transferred to $250 \mathrm{ml}$ flask without propanol addition, respectively. After all of cells transferred to new flasks, cell growth was measured by $30 \mathrm{~min}$ interval for $2 \mathrm{hr}$. Each measurement was performed in triplicate.

에 비해 민감하게 반응하여 세포의 성장이 더 많이 저해를 받았으며 비 성장속도도 감소하였다(Table 6). 또한, $\mathrm{rpoH} H$ 유전 자를 cloning하여 도입한 complementation된 균주(DRP17/ $\mathrm{pBRH} 46)$ 는 프로판올을 첨가한 후 세포의 비 성장속도가 야생 주와 비슷한 정도로 회복되었다. 따라서, 대장균에서 $\mathrm{RpoH}$ 에 의한 heat shock response관련 유전자들의 발현은 프로판올 스트레스를 극복하기 중요한 보호기작으로 사료된다.

\section{감사의 글}

이 논문은 2009년도 정부(교육과학기술부)의 재원으로 한 국연구재단의 지원을 받아 수행된 기초연구사업임(20090068974). 본 연구는 지식경제부와 한국산업기술진흥원의 전 략기술인력양성사업으로 수행된 결과임.

\section{References}

1. Alexandre, H., Rousseaux, I. and Charpentier, C. 1994. Relationship between ethanol tolerance, lipid composition and plasma membrane fluidity in Saccharomyces cerevisiae and Klockera apiculata. FEMS Microbiol. Lett. 124, 17-22.

2. Alexeeva, S., Hellingwerf, K. J. and Mattos, T. 2003. Requirement of ArcA for redox regulation in Escherichia coli under microaerobic but not anaerobic or aerobic conditions. J. Bacteriol. 85, 204-209.

3. Alsaker, K. V., Paredes, C. and Papoutsakis, E. T. 2010. Metabolite stress and tolerance in the production of biofuels and chemicals: Gene-expression-based systems analysis of butanol, butyrate, and acetate stresses in the anaerobe Clostridium acetobutylicum Biotech Bioeng. 105, 1131-1147.

4. Atsumi, S., Cann, A. F., Connor, M. R., Shen, C. R., Smith, K. M., Brynildsen, M. P., Chou, K. J. Y., Hanai, T. and Liao, J. C. 2007. Metabolic engineering of Escherichia coli for 1-butanol production. Metab. Eng. 10, 305-311.

5. Atsumi, S., Hanai, T. and Liao, J. C. 2008. Non-fermentative pathways for synthesis of branched-chain higher alcohols as biofuels. Nature 451, 86-90.

6. Baba, T., Ara, T., Hasegawa, M., Takai, Y., Okumura, Y., Baba, M., Datsenko, K. A., Tomita, M., Wanner, B. L. and Mori, H. 2006. Construction of E. coli K-12 in-frame, single-gene knockout mutants: the Keio collection. Mol. Syst. Biol. 2, 1-11.

7. Baer, S. H., Blaschek, H. P. and Smith, T. L. 1987. Effect of butanol challenge and temperature on lipid composition and membrane fluidity of butanol tolerant Clostridium acetobutylicum Appl. Environ. Microbiol. 53, 2854-2861.

8. Bowles, L. K. and Ellefson, W. L. 1985. Effects of butanol on Clostridium acetobutylicum Appl. Environ. Microbiol. 50, 1165-1170.

9. Brynildsen, M. P. and Liao, J. C. 2009. An integrated network approach identifies the isobutanol response network of Escherichia coli. Mol. Syst. Biol. 5, 1-13.

10. Buttke, T. M. and Ingram, L. O. 1978. Mechanism of ethanol-induced changes in lipid composition of Escherichia coli. Inhibition of saturated fatty acid synthesis in vivo. Biochemistry 17, 637-644.

11. Buttke, T. M. and Ingram, L. O. 1980. Ethanol-induced changes in lipid composition of Escherichia coli. Inhibition of saturated fatty acid synthesis in vitro. Arch Biochem Biophys. 203, 565-571.

12. Chuang, S. E. and Blattner, F. R. 1993. Characterization of twenty-six new heat shock genes of Escherichia coli. J. 
Bacteriol. 175, 5242-5252.

13. Cotter, P. A. and Gunsalus, R. P. 1992. Contribution of the frr and $\operatorname{arc} A$ gene products in coordinate regulation of cytochrome o and d oxidase ( $c y 0 A B C D E$ and $c y d A B)$ genes in Escherichia coli. FEMS Microbiol. Lett. 70, 31-36.

14. Fic, E., Bonarek, P., Gorecki, A., Kedracka-Krok, S., Mikolajczak, J., Polit, A., Tworzydlo, M., DziedzickaWasylewska, M. and Wasylewski, Z. 2009. cAMP receptor protein from Escherichia coli as a model of signal transduction in proteins. J. Mol. Microbiol. Biotechnol. 17, 1-11.

15. Gama-Castro, S., Jimenez-Jacinto, V., Peralta-Gil, M., Santos-Zavaleta, A., Penaloza-Spinola, M. I., ContrerasMoreira, B., Segura-Salazar, J., Muniz-Rascado, L., Martinez-Flores, I., Salgado, H., Bonavides-Martinez, C., Abreu-Goodger, C., Rodriguez-Penagos, C., Miranda-Rios, J., Morett, E., Merino, E., Huerta, A. M., Trevino-Quintanilla, L. and Collado-Vides, J. 2008. RegulonDB (version 6.0): gene regulation model of Escherichia coli $\mathrm{K}-12$ beyond transcription, active (experimental) annotated promoters and Textpresso navigation. Nucleic Acids Res. 36, 120-124.

16. Gonzalez, R., Tao, H., Purvis, J. E., York, S. W., Shanmugam, K. T. and Ingram, L. O. 2003. Gene array-based identification of changes that contribute to ethanol tolerance in ethanologenic Escherichia coli: Comparison of KO11 (Parent) to LY01 (resistant mutant). Biotechnol. Prog. 19, 612-623.

17. Kubota, S., Takeo, I., Kume, K., Kanai, M., Shitamukai, A., Mizunuma, M., Miyakawa, T., Shimoi, H., Iefuji, H. and Hirata, D. 2004. Effect of ethanol on cell growth of budding yeast: Genes that are important for cell growth in the presence of ethanol. Biosci. Biotechnol. Biochem 68, 968-972.

18. Lepage, C., Fayolle, F., Hermann, M. and Vandecasteele, J. P. 1987. Changes in membrane-lipid composition of Clostridium acetobutylicum during acetone butanol fermentation-Effects of solvents, growth temperature and $\mathrm{pH}$. J. Gen. Microbiol. 133, 103-110.

19. Lin, Y. and Tanaka, S. 2006. Ethanol fermentation from biomass resources: current state and prospects. Appl. Microbiol. Biotechnol. 69, 627-642.

20. Liu, S. and Qureshi, N. 2009. How microbes tolerate ethanol and butanol. New Biotech 26, 117-121.
21. Nobelmann, B. and Lengeler, J. W. 1996. Molecular analysis of the gat genes from Escherichia coli and of their roles in galactitol transport and metabolism. J. Bacteriol. 178, 6790-6795.

22. Ogawa, Y., Nitta, A., Uchiyama, H., Imamura, T., Shimoi, H. and Ito, K. 2000. Tolerance mechanism of the ethanol-tolerant mutant of sake yeast. J. Biosci. Bioeng. 90, 313-320.

23. Park, S. J., Tseng, C. P. and Gunsalus, R. P. 1995. Regulation of succinate dehydrogenase $(s d h C D A B)$ operon expression in Escherichia coli in response to carbon supply and anaerobiosis: role of ArcA and Fnr. Mol. Microbiol. 15, 473-482.

24. Qureshi, N. and Blaschek, H. P. 2001. Recent advances in ABE fermentation: hyper-butanol producing Clostridium beijerincki BA101. J. Ind Microbiol. Biotech 27, 287-291.

25. Repoila, F., Majdalani, N. and Gottesman, S. 2003. Small non-coding RNAs, coordinators of adaptation processes in Escherichia coli. the RpoS paradigm. Mol. Microbiol. 48, 855-861.

26. Salgueiro, S. P., Sá-Correia, I. and Novais, J. M. 1988. Ethanol-induced leakage in Saccharomyces cerevisiae. Kinetics and relationship to yeast ethanol tolerance and alcohol fermentation productivity. Appl. Environ. Microbiol. 54, 903-909.

27. Salmon, K., Hung, S. P., Mekjian, K., Baldi, P., Hatfield, G. W. and Gunsalus, R. P. 2003. Global gene expression profiling in Escherichia coli K12. The effects of oxygen availability and FNR. J. Biol. Chem 278, 29837-29855.

28. Sambrook, J. and Russell, D. W. 2001. Molecular cloning: a laboratory manual, $3^{\text {rd }}$ ed. Cold Spring Harbor Laboratory Press, Cold Spring Harbor, N.Y.

29. Shen, C. R. and Liao, J. C. 2008. Metabolic engineering of Escherichia coli for 1-butanol and 1-propanol production via the keto-acid pathways. Metab. Eng. 10, 312-320.

30. Terracciano, J. S. and Kashket, E. R. 1986. Intracellular conditions required for initiation of solvent production by Clostridium acetobutylicum Appl. Environ. Microbiol. 52, 86-91.

31. Tomas, C. A., Welker, N. E. and Papoutsakis, E. T. 2003. Overexpression of groESL in Clostridium acetobutylicum results in increased solvent production and tolerance, prolonged metabolism, and large changes in the cell's transcriptional program. Appl. Environ. Microbiol. 69, 4951-4965. 


\section{초록 : 대장균에서 프로판올 스트레스에 관한 전사분석}

박혜진 · 이진호*

(경성대학교 식품생명공학과)

대장균 야생주와 프로판올 내성 변이주에서 프로판올 스트레스에 의해 발현이 크게 변화하는 유전자를 DNA microarray 기술을 이용하여 비교 분석하였다. 프로판올 첨가한 야생주와 무첨가한 야생주 사이의 RNA 발현 연 관값은 0.949 이며, 50 개의 유전자 발현이 2 배 이상 변화하였다. 프로판올을 첨가한 내성변이주와 무첨가한 변이주 사이의 연관값은 0.952 이며, 71 개의 유전자 발현이 크게 변화하였다. 그러나, 야생주와 변이주 사이의 연관값은 프로판올 무첨가한 조건과 첨가한 조건에서 각각 0.992 및 0.974 로 매우 높았으며, 2 배 이상의 발현차이를 나타내 는 유전자는 각각 1 개 및 2개로, 두 균주는 매우 유사한 발현양상을 보였다. 야생주 또는 변이주에서 프로판올 스트레스에 반응하는 대표적인 유전자들의 특징은 많은 열충격 반응에 관여하는 유전자들의 발현이 크게 증가하 였으며, 리보소옴 합성에 필요한 많은 유전자들의 발현이 감소하였다. 또한, 전사조절인자들인 $\mathrm{ArcA}, \mathrm{CRP}, \mathrm{FNR}$, H-NS, GatR, PurR에 의해 조절받는 유전자들의 발현이 크게 변화하였으며, 시그마인자들 중에서는 $\mathrm{RpoH}$ 에 의 해서 발현되는 유전자들의 발현이 크게 증가하였다. $r p o H$ 가 정상적으로 발현되지 못하는 변이주와 야생주를 이 용한 프로판올 내성정도를 측정한 결과, $\mathrm{RpoH}$ 는 대장균에서 프로판올 스트레스에 적응하는데 중요한 기능을 하 는 것으로 확인되었다. 